\title{
PENINGKATAN REGULASI PERILAKU MELALUI COGNITIVE BEHAVIOR PLAY THERAPY PADA KELOMPOK ANAK DIDIK LEMBAGA PEMASYARAKATAN DI TANGERANG
}

\author{
Naomi Soetikno ${ }^{1}$, Rahmah Hastuti ${ }^{2}$ \\ ${ }^{1}$ Fakultas Psikologi, Universitas Tarumanagara Jakarta \\ Email:naomis@fpsi.untar.ac.id \\ ${ }^{2}$ Fakultas Psikologi, Universitas Tarumanagara Jakarta \\ Email: rahmahh@fpsi.untar.ac.id
}

\begin{abstract}
Teenagers who violate the rules of criminal law are in the Lembaga Pemasyarakatan (Penitentiary). In a correctional institution for boys in Tangerang, adolescents undergo their prison terms and still get the opportunity to attend school or learn skills. In the interaction of adolescents in correctional institutions, they are often complained about behavior that is not according to rules such as theft, fighting or disturbing friends/ bullying. The inability of adolescents to control their behavior even though they are already in correctional institutions illustrates their difficulties in regulating behavior. Behavioral regulation is part of the human executive function to be able to direct behavior in a purpose so as to make the right decision. Behavioral regulation can be trained with psychological therapy using the game approach. Cognitive Behavioral Play Therapy applied to 10 adolescents in correctional institutions shows that there was a change in the value of behavioral regulation.
\end{abstract}

Kata kunci: Regulasi perilaku, Cognitive Behavior Play Therapy, Kelompok Terapi, LPKA

\section{PENDAHULUAN}

Lembaga Pemasyarakatan Khusus Anak (selanjutnya LPKA) menampung anak yang berhadapan dengan hukum yakni anak yang berkonflik dengan hukum, anak yang menjadi korban tindak pidana, dan anak yang menjadi saksi tindak pidana. Anak yang berhadapaan dengan hukum ini adalah anak yang telah berusia 12 sampai dengan 18 tahun (UU Peradilan Anak no 11 tahun 2012). Di Indonesia terdapat sejumlah lembaga pemasyarakatan yang menampung anak, salah satunya adalah di Tangerang yang masuk dalam wilayah Banten. Pada LPKA Pria di Tangerang pada bulan Februari 2018 tercatat sejumlah 22 anak tahanan dan 88 anak pidana ("Sistem Database Pemasyarakatan", 2011).

Permasalahan yang diketahui dari hasil pengamatan langsung kami sebagai psikolog yang memberikan layanan psikologis di LPKA di Salemba pada tahun 2017 maupun hasil dari wawacara pribadi dengan petugas pembinaan anak di LPKA Tangerang pada 15 Februari 2018 diketahui berbagai permasalahan yang terjadi pada anak didik di lapas (selanjutnya disebut andikpas). Permasalahan yang terjadi pada andikpas adalah masih terdapatnya perilaku yang melanggar aturan di dalam lapas seperti pencurian, perkelahian, saling mengejek/ bullying, membawa handphone yang sebenarnya dilarang, merokok. Lokasi pelaksanaan abdimas yang dipilih merupakan Lembaga Pembinaan Khusus Anak, hal ini dikarenakan masih terdapatnya anak yang berkonflik dengan hukum yang tidak mendapatkan pembinaan secara baik dan benar, dan masih terdapatnya penggabungan dalam satu blok antara anak dengan dewasa/remaja sehingga dikhawatirkan ada pengaruh negatif (Yuliyanto \& Ernis, 2016). 
Perilaku melanggar aturan disebabkan oleh banyak faktor, seperti diketahui bahwa regulasi emosi dan juga regulasi diri yang rendah (Carlo et al, 2012; Kemp et al, 2017; Kim, 2017), faktor kepribadian (Archer, 2009; Carlo et al, 2012). Tindakan melawan aturan sering ditampilkan dalam bentuk agresi, berbagai macam perilaku yang ditampilkan baik berbentuk verbal maupun non-verbal. Agresi merupakan perilaku yang bertujuan untuk menyakiti orang lain. Perilaku agresi berkaitan dengan faktor bawaan, faktor hasil interaksi dengan lingkungan, juga mekanisme berpikir (Archer, 2009). Bentuk agresi sangat berkaitan dengan keyakinan pemikiran yang dimiliki (Bailey \& Ostrov, 2008), juga kontrol diri (Denson et al, 2011).

Regulasi perilaku yang merupakan bagian dari fungsi eksekutif pada individu dan berkaitan dengan perilaku agresi atau perilaku yang melawan hukum (Jones, 2002; Koolen et al, 2013; Soetikno \& Basaria, 2013). Regulasi perilaku terdiri dari kemampuan inhibisi, adaptasi, dan kontrol emosi (Riyadi et al., 2009). Regulasi perilaku yang seringnya disebut dengan regulasi diri digambarkan sebagai kemampuan individu dalam mengendalikan diri agar berperilaku yang dapat diterima oleh khalayak umum, mengendalikan dorongan sehingga dapat menahan diri untuk melakukan sesuatu. Regulasi diri juga menunjukkan pada pengendalian energi, emosi, perhatian dan perilaku sehingga dapat diterima di lingkungan sosial serta dapat mendukung pencapaian tujuan. Regulasi diri ditunjukkan dengan sikap tenang, fokus, dan waspada (Lowry, 2016).

Tujuan umum dari kegiatan pengabdian kepada masyarakat ini adalah mengurangi pelanggaran aturan yang dilakukan andikpas di dalam LPKA Tangerang. Secara khusus, kegiatan ini bertujuan untuk. meningkatkan regulasi perilaku melalui pemberian intervensi kelompok pada andikpas. Pemberian intervensi kelompok dengan metode Cognitive Behavioral Play Therapy merupakan langkah kerja yang dapat diterapkan kepada andikpas. Cognitive Behavior Play Therapy (CBPT) adalah jenis terapi yang menggabungkan Cognitive Behavior Therapy (CBT) dengan terapi bermain. CBT didasarkan pada asumsi bahwa hal-hal yang dipikirkan oleh individu akan memengaruhi perasaannya serta yang dilakukannya. Basis penelitian untuk CBT dan manfaatnya telah berhasil digunakan dengan orang dewasa, remaja, dan anak-anak. Ada banyak jenis terapi bermain dan sejarahnya sangat luas. Namun, mereka semua memiliki dasar menggunakan bermain sebagai sarana untuk: membantu mencegah anak-anak dari kesulitan, membantu anak untuk tumbuh dan berkembang. Cognitive Behavioral Play Therapy dari riset sebelumnya telah berhasil diterapkan untuk anak-anak dan remaja (Badamian \& Moghaddam, 2017).

Cognitive Behavior Therapy merupakan salah satu bentuk intervensi yang berpusat pada pemikiran dan tingkah laku yang menimbulkan permasalahan pada diri, intervensi ini juga membantu individu untuk memusatkan perhatian pada kesadaran sosial dan pemacahan masalah dalam permasalahan yang dimiliki (Busari dikutip dalam Karismatika, 2014). .). Secara khusus, CBPT telah terbukti berhasil dalam mengobati selective mutism, gangguan kecemasan, pelecehan seksual, masalah tidur, dan efek dari perceraian orang tua (Knell; Knell \& Darsari; Knell \& Ruma dikutip dalam Bratton, Rhine, \& Jones, 2005). Cognitive Behavior Play Therapy (CBPT) digunakan sebagai intervensi kelompok dengan menggunakan permainan sebagai media untuk mendukung teknik cognitive behavior yang yang diberikan (Knell, \& Dasari, 2011). CBPT dapat diterapkan dalam kelompok remaja sehingga dapat meningkatkan keterampilan sosial dan pengambilan keputusan. Didalam kegiatan berkelompok, remaja akan mendapatkan pertukaran pengalaman yang mendukung 
kemampuan pengambilan keputusannya (Fazio-Griffith \& Marino, 2017). CBPT juga dapat digunakan untuk mereduksi agresi anak, menunjukkan keterampilan baru, menawarkan peluang untuk diskusi, memodelkan keterampilan baru, dan mengatasi masalah yang dialami anak dan remaja. Jenis terapi bermain telah ditemukan menjadi sarana pengobatan yang efektif untuk anak-anak (Bratton, Ray, Rhine, \& Jones, dikutip dalam Graham, n.d.). Dengan pendekatan CBPT yang digunakan pada intervensi kelompok andikpas diharapkan akan meningkatkan regulasi perilaku. Intervensi kelompok ini akan membuat andikpas menjadi mampu untuk mengikuti aturan yang ada di dalam Lapas.

\section{METODE PELAKSANAAN}

Desain penelitian pada kegiatan pengabdian kepada masyarakat adalah quasi experimental design, pre-test, post-test dengan mengetahui efektivitas dari kegiatan yang diberikan melalui pengukuran kuantitatif sebelum dan setelah kegiatan.

Partisipan adalah sepuluh remaja dengan starus anak didik LPKA, memiliki permasalahan perilaku yakni kasus agresi sebagai kasus pidana, berperilaku melanggar aturan di LPKA sehingga masuk sel tahanan.

Psikoterapi dalam bentuk kelompok pada anak didik LPKA dan menggunakan pendekatan CBPT. Kegiatan CBPT dilakukan dua kali dalam seminggu berturut-turut selama empat minggu.

Pelaksana kegiatan PKM adalah dua orang dosen fakultas Psikologi Universitas Tarumanagara dan tiga orang mahasiswa S2 jurusan Profesi Psikologi Klinis Universitas Tarumanagara.

Pengukuran regulasi perilaku dilakukan dengan alat ukur BRIEF-BI yang menghasilkan nilai BRI (Behavior Regulation Index). Nilai BRI yang tinggi menunjukkan adanya difungsi atau permasalahan pada regulasi perilaku, dengan nilai kategori normal adalah 0-65, dan kategori permaslahana klinis adalah >65 pada skala abnormalitas yang telah terstandardisasi secara nasional (Riyadi et al., 2009). Pengukuran regulasi perilaku dilakukan sebanyak dua kali, yakni sebelum kegiatan PKM diberikan dan seminggu setelah PKM untuk melihat perubahan perilaku yang tampak setelah diberikan psikoterapi.

\section{HASIL DAN PEMBAHASAN}

Dari sepuluh peserta PKM, diketahui nilai BRI sebelum kegiatan yakni adanya dua andik yang memiliki nilai BRI < 65, dan delapan lainnya memiliki nilai BRI > 65 yang masuk kategori permasalahan klinis.

Dari kedua andik yang memiliki nilai BRI $<65$ menunjukkan perilaku hati-hati saat berbicara, terencana saat mengungkapkan pendapat, lebih banyak diam dan mengamati selama di LPKA. Sedangkan, delapan lainnya yang memiliki nilai BRI > 65 menunjukkan perilaku banyak bercanda dan tidak mendengarkan, impulsif dalam berbicara, tidak terencana saat permainan (trial and error).

Hasil dari post tes menunjukkan perubahan yang signifikan, bahwa setelah kegiatan PKM diberikan dapat diketahui bahwa nilai BRI dari seluruh andik mengalami perubahan menjadi 
lebih baik yang ditandai dengan nilai BRI yang menurun.digambarkan pada gambar 1, bahwa pada post-test didapatkan andik yang memiliki nilai di bawah 65 terdapat 4 orang sedangkan pada hasil pre-test terdapat 2 orang saja.

Berikut ini pada gambar 1 diketahui perbandingan nilai pre-test dan post-tes dari setiap andik.

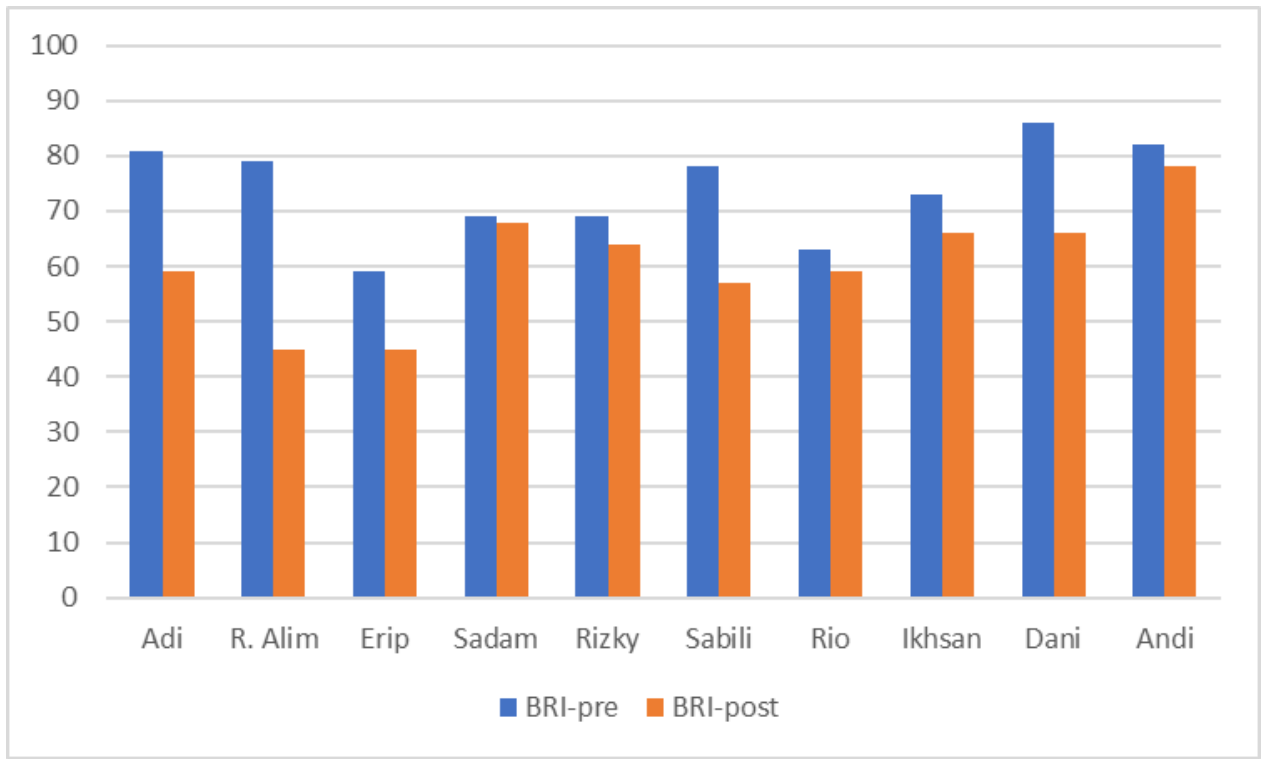

Gambar 1. Perbandingan Nilai Pre-Test Dan Post-Tes Dari Setiap Andik

Dengan didapatkan hasil BRI pre-test dan post-test dilakukan pengujian uji perbedaan, paired sample T-test dan diketahui bahwa nilai $\mathrm{t}=3.880 \operatorname{sig} 9, \mathrm{p} 0.004<0.05$, menunjukkan bahwa perbedaan hasil pre-test dan post-test adalah signifikan.

Selama kegiatan PKM berlangsung, sepuluh andik pas mengikuti kegiatan secara penuh yakni hadir sebanyak enam kali berturut-turut selama tiga minggu. Peserta juga menunjukkan keaktifan dalam mengikuti kegiatan seperti berpartisipasi memberikan ide, insiatif mengajak teman, berkegiatan bersama sesuai dengan arahan yang diberikan. Permainan dilakukan dalam kelompok dan dirancang untuk memiliki tingkat kesulitan yang berbeda. Permainan ditentukan berdasarkan tujuan kegiatan.

Berikut ini penjelasan mengenai sesi-sesi dalam kegiatan CBPT.

\section{Sesi satu. Automatic Thought Record}

Tujuan sesi ini yaitu mengetahui pikiran pertama yang muncul ketika melihat sebuah gerakan tertentu dari lingkungan sekitar. Kegiatan yang dilakukan yaitu setiap peserta mengambil satu buah kertas undian yang berisi kalimat. Setiap peserta diminta untuk menjelaskan sebuah kalimat yang mereka dapat dengan menggunakan gerakan tanpa suara. Peserta-perserta lain mencoba untuk menebak kalimat tersebut sebelum waktu habis. Berikutnya, peserta mendiskusikan setiap peserta memiliki pikiran pertama yang berbeda-beda terhadap suatu gerakan.

\section{Sesi dua. Cognitive Restructuring}

Tujuan dari sesi ini yaitu menyesuaikan pikiran individu dengan situasi di lingkungan, serta membangun kerja sama kelompok dengan mendengarkan. Kegiatan yang dilakukan yaitu setiap peserta diminta menggambar di kertas yang telah disediakan bersama-sama pada satu kertas tanpa berdiskusi terlebih dahulu. Setelah gambar selesai, mereka harus mendiskusikan gambar yang mereka buat dan membentuk satu cerita utuh. Selesai permainan, akan dilakukan diskusi 
bahwa pemikiran yang awal mengenai gambar dapat diubah sehingga dapat sesuai dengan lingkungan.

\section{Sesi tiga. Controlling Your Thought}

Tujuan kegiatan ini yaitu memahami persepsi diri dan orang lain (lingkungan) terhadap diri sendiri dan mengarahkannya ke hal yang positif.

Kegiatan yang dilakukan yaitu setiap peserta diminta untuk memilih emoticon yang menurut mereka sesuai dengan dirinya masing-masing. Setelah itu, para peserta diminta untuk duduk melingkar. Setiap peserta akan maju ke depan dan diminta memperagakan perilaku positif seseorang dari kelompok. Para peserta lainnya diminta untuk menebak siapa yang sedang diperagakan.

\section{Sesi empat. Controlling Your Behavior}

Kegiatan yang dilakukan pada sesi ini yaitu semua peserta diminta untuk berbaris lurus dengan balon di antara setiap orang. Mereka diminta untuk menyeimbangkan balon di antara tubuh mereka tanpa menggunakan tangan. Peserta kemudian diminta untuk berjalan melewati berbagai rintangan sesuai dengan jalur yang telah ditentukan. Peserta diminta untuk melewati rintangan sebelum musik selesai dimainkan.

\section{Sesi lima. Problem Solving Skill}

Tujuannya yaitu memahami dalam menyelesaikan masalah ada banyak alternatif yang memiliki kemungkinan lebih baik serta memahami pemikiran atau pendapat mereka dapat saja keliru. Berikutnya, membangun kerja sama kelompok dengan cara berdiskusi untuk memecahkan masalah. Kegiatan yang dilakukan berupa peserta diminta mengurutkan alat dari yang paling mudah hingga yang paling sulit dipindahkan. Tiap peserta memilih alat bantu yang menurut mereka paling mudah untuk memindahkan. Peserta diminta memindahkan benda dari satu titik ke titik lain secara berkelompok dengan menggunakan alat bantu yang mereka pilih.

Setelah menerapkan beragam kegiatan pada tiap sesinya mengacu pada konteks CBPT, hasil dari data yang diperoleh melalui pre-test dan post-test kemudian dianalisis. Keterlibatan peserta PKM dapat disimpulkan bahwa peserta yang memiliki permasalahan dalam regulasi perilaku memiliki upaya untuk meregulasi perilakunya selama kegiatan berlangsung. Kesediaan untuk mengikuti kegiatan, menyesuaikan diri dengan aturan, menunjukkan aktivitas bersama merupakan indikasi dari regulasi perilaku pada kegiatan.

\section{KESIMPULAN}

Dari pemberian psikoterapi CBPT kepada sepuluh orang andikpas di LPKA yang menunjukkan permasalahan regulasi perilaku didaptkan bahwa adanya perubahan nilai BRI yang ditampilkan. Perubahan nilai BRI dari peserta menunjukkan adanya efektivitas dari psikoterapi yang diberikan dan manfaat psikoterapi ini dapat diterima oleh peserta.

Saran dapat diberikan kepada LPKA untuk mengikuti modul psikoterapi dengan pendekaan CBPT dalam pembinaan kepada andikpas.

\section{Ucapan Terima Kasih}

Terima kasih diberikan kepada Direktorat Penelitian dan Pengabdian Kepada Masyarakat Universitas Tarumanagara atas pemberian dana pengabdian kepada masyarakat, sehingga kegiatan ini dapat berlangsung dengan lancar. Kepada institusi LPKA Tangerang yang telah bersedia menerima manfaat PKM yang diberikan, serta kepada tim pelaksana yakni mahasiswa profesi psikologi klinis Universitas Tarumanagara. 


\section{REFERENSI}

Archer, J. (2009). The nature of human aggression. International Journal of Law and Psychiatry, 32, 202-208. doi:10.1016/j.ijlp.2009.04.001

Badamian, R., \& Moghaddam, N. E. (2017). The effectiveness of cognitive-behavioral play therapy on flexibility in aggressive children. Journal of Fundamentals of Mental Health, p. 133-137.

Bailey, C.A. \& Ostrov, J.M. (2008). Differentiating forms and functions of aggression in emerging adults: Associations with hostile attribution biases and normative beliefs. Youth Adolescence, 37:713-722. DOI 10.1007/s10964-007-9211-5

Bratton, S., Ray, D., Rhine, T., \& Jones, L. (2005). The efficacy of play therapy with children: A meta-analytic review of the outcome research. Professional Psychology: Research and Practice, 36(4), 376-390.

Carlo, G., Mestre, M.V., McGinley, M.M., Samper, P., Tur, A., \& Sandman, D. (2012). The interplay of emotional instability, empathy, and coping on prosocial and aggressive behaviors. Personality and Individual Differences. 53, 675-680.

Denson, T.F., Capper, M.M., Oaten, M., Friese, M., \& Schofield, T.P. (2011). Self-control training decreases aggression in response to provocation in aggressive individuals. Journal of Research in Personality, 45: 252-256.

Fazio-Griffith, L.J., \& Marino, R. (2017). A Cognitive-Behavioral Play Therapy (CBPT) approach for adolescents' pro-social skill development in the school setting: In emerging research in play therapy. Child Counseling, and Consultation. DOI: 10.4018/978-1-52252224-9.ch008

Graham, A. (n.d.). Cognitive behavior play therapy. Retrieved from http://www.annegraham.ca/what-is-play-therapy.html

Jones, C. (2002). Executive and social cognitive function in reactive proactive aggressive young boys. Dissertation. Simon Fraser University.

Karismatika, I. (2014). Terapi kognitif perilaku untuk remaja dengan gangguan tingkah laku. Jurnal Sains dan Praktik Psikologi, 2(3), 296-301.

Kemp, K., Thamotharan, S., Poindexter, B., Barker, D., Tolou-Shams, M., \& Houck, C.D. (2017). Emotion regulation as a predictor of juvenile arrest. Criminal Justice and Behavior. DOI: doi.org/10.1177/0093854817695842

Kim, Y.J. (2017). Longitudinal relationship between Emotion regulation and aggressive behavior: The moderating effect of caregiving. Dissertation. Submitted to the Graduate Faculty of School of Social Work, University of Pittsburgh.

Knell, S. M., \& Dasari, M. (2011). Cognitive-behavioral play therapy. In S. W. Russ \& L. N. Niec (Eds.) Play in clinical practice: Evidence-based approaches (pp. 236-263). New York, NY, US: Guilford Press.

Koolen, S., Poorthuis, A., \& Aken, M.A. G. (2012). Cognitive distortions and self-regulatory personality traits associated with proactive and reactive aggression in early adolescence. 
Cogn Ther Res. 36:776-787. DOI 10.1007/s10608-011-9407-6

Lowry (2016). What is behaviour regulation? And what does it have to do with language development?. Hanen Centre. Retrieved online February 16, 2018: http://www.hanen.org/helpful-info/articles/what-is-behaviour-regulation--and-what-does-ithav.aspx

Riyadi, E.I., Wiguna, T., \& Irmansyah. (2009). Behavior rating inventory of executive fnction version bahasa Indonesia (BRIEF-BI). Thesis. Psychiatry Department, Faculty of Medical, Universitas Indonesia, Cipto Mangunkusumo Hospital, Jakarta.

Sistem Database Pemasyarakatan. (2011). Diunduh dari http://smslap.ditjenpas.go.id/public/grl/detail/monthly/upt/db5b9480-6bd1-1bd1-fbe3313134333039

Soetikno, N. \& Basaria, D. (2015). Subjective well-being dan regulasi diri remaja pelaku tindak kekerasan: Studi pada anak pidana di Lembaga Pemasyarakatan Anak Pria Tangerang). Conference: Temu Ilmiah Nasional APSIFOR V, Universitas Dhyana PuraBali.

Yuliyanto \& Ernis, Y. (2016). Lembaga pembinaan khusus anak dalam perspektif sistem peradilan pidana anak. Diunduh dari

http://sipkumham.balitbangham.go.id/assets/img/dokumenpenelitian/PTL20171109015102016_ A20.pdf 